\title{
触 New Disease Reports \\ First report of Alternaria sp. causing leaf blight disease on parthenium weed in India
}

M. Kaur and N.K. Aggarwal*

Department of Microbiology, Kurukshetra University, Kurukshetra 136119, India

*E-mail: mani7yu@gmail.com

Received: 25 Oct 2014. Published: 23 May 2015. Keywords: biological control

Congress grass, Parthenium hysterophorus (Asteraceae), is known as a notorious weed in India and around the world (Kaur et al., 2014). From 2012 to 2014, a survey on the occurrence of the natural fungal pathogens of $P$. hysterophorus was conducted in Haryana state, India. During the survey, a severe leaf blight disease was regularly reported on parthenium leaves in different parts of the Kurukshetra district of Haryana (Fig. 1). A fungus was isolated from the infected leaves that yielded grey colonies on potato dextrose agar (PDA). Mycelium was septate and hyaline; conidia were solitary, dark brown, muriform with a tapering long beak and chlamydospores were produced abundantly in chains and clusters (Fig. 2). Conidia (17.5-62.5 x 10-17.5 $\mu \mathrm{m})$ had one to six transverse septa and none or up to two longitudinal septa, with beak in the size range 0-20 x 5-7.5 $\mu \mathrm{m}$. The conidial morphology showed that the pathogen belongs to the genus Alternaria (Ellis, 1971) as confirmed by CABI UK (IMI No. 503549). Molecular analysis of the ITS1-5.8S-ITS2 rDNA region carried out at CABI UK confirmed the pathogen as Alternaria sp. but failed to provide identification to species level. Subsequently, however on submitting the pathogen isolate to Macrogen Inc., Korea, sequence analysis (GenBank Accession No. KM213867) showed 99-100\% similarity with A. macrospora strain B isolated from cotton (DQ156342). Unfortunately it is not clear whether this isolate was A. macrospora Zimm. or should be referred to other taxons (e.g. A. macrospora (Sacc.) Mussat) that are synonyms of $A$. brassicae.

In vitro pathogenicity of the Alternaria sp. isolate was demonstrated by placing seven-day-old mycelial plugs $(5 \mathrm{~mm})$ of the pathogen on detached parthenium leaves that produced symptoms from which the same Alternaria sp. was re-isolated. To confirm the in vivo pathogenicity of this isolate, a spore suspension of $2 \times 10^{5}$ spores $/ \mathrm{ml}$ was sprayed on parthenium plants in pothouse conditions. Typical disease symptoms were observed on leaves and the inoculated pathogen was re-isolated, thus confirming pathogenicity to Parthenium hysterophorus and fulfilling Koch's postulates.
There are reports of A. alternata and A. zinniae attacking pathenium from Venezuela and India respectively (Urtiaga, 1986; Sharma \& Gupta, 2008) but our isolate does not match either of these species descriptions (Ellis, 1971). However, this is the first record of another species of Alternaria, possibly A. macrospora, on parthenium weed. A. macrospora is known to be pathogenic to cotton and some malvaceous weeds (Walker $\&$ Sciumbato, 1981). Work to date on this isolate (isolate MKP2) has shown that it is not pathogenic to cotton, wheat or sugarcane, suggesting potential for this isolate as a biocontrol for parthenium weed (Kaur et al., 2014).

\section{Acknowledgements}

The authors are thankful to the Director, CABI, International Mycological Institute, Egham, England for confirming the identification of the isolate.

\section{References}

Ellis MB, 1971. Dematiaceous Hyphomycetes. Kew Surry, UK: Commonwealth Mycological Institute.

Kaur M, Aggarwal NK, Kumar V, Dhiman R, 2014. Effects and Management of Parthenium hysterophorus a weed of global significances. International Scholarly Research Notices, Article ID 368647, 12 pages. http://dx.doi.org/10.1155/2014/368647

Sharma DD, Gupta AK, 2008. Alternaria zinnia on Parthenium hysterophorus. Bulletin OEPP/EPPO Bulletin 28, 217. http://dx.doi.org/10.1111/j.1365-2338.1998.tb00724.x

Urtiaga R. 1986. Indice de enfermedades en plantas de Venezuela y Cuba. Barquisimeto, Venezuela: Impresos en Impresos Nuevo Siglo.

Walker HL, Sciumbato GL, 1981. Host range studies on four Alternaria isolates pathogenic to cotton (Gossypium spp.) or spurred anoda (Anoda cristata). Plant Science Letters 22, 71-75.

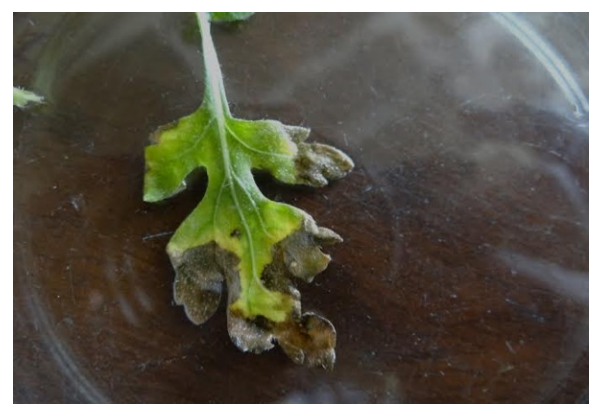

Figure 1

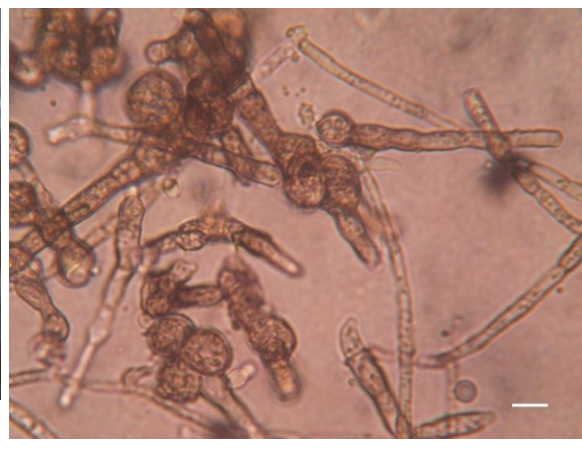

Figure 2

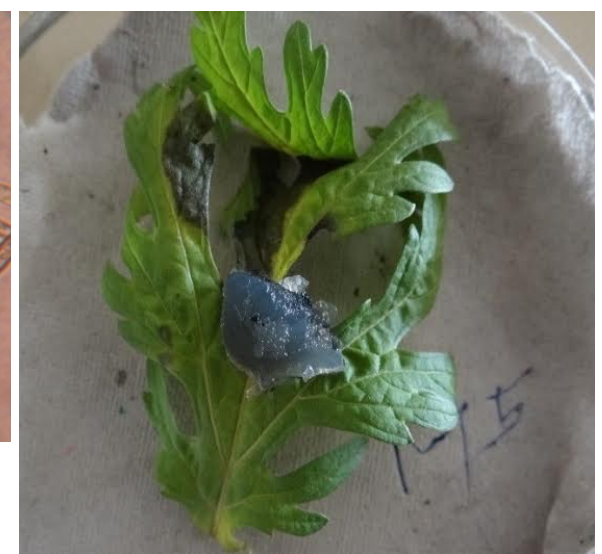

Figure 3

To cite this report: Kaur M, Aggarwal NK, 2015. First report of Alternaria sp. causing leaf blight disease on parthenium weed in India. New Disease Reports 31, 25. http://dx.doi.org/10.5197/j.2044-0588.2015.031.025

(C) 2015 The Authors

This report was published on-line at www.ndrs.org.uk where high quality versions of the figures can be found. 